\title{
MYRONOSETS - A NEW PRODUCTIVE AND HIGH-PROTEIN WINTER TRITICALE CULTIVAR, ADAPTED TO THE WOODLANDS/FOREST-STEPPE AND FOREST-STEPPE OF UKRAINE
}

\author{
Moskalets V.V. ${ }^{1}$, Moskalets V.I. ${ }^{2}$, Moskalets T.Z. ${ }^{3}$, Grynyk I.V. ${ }^{1}$, Demidov A.A. ${ }^{3}$, Voloshchuk S.I. ${ }^{3}$, \\ Khomenko S.O. ${ }^{3}$ \\ ${ }^{1}$ Institute of Horticulture National Academy of Agrarian Sciences of Ukraine \\ ${ }^{2}$ Nosivka Breeding and Research Station the V.M. Remeslo Myronivka Institute of wheat National \\ Academy of Agrarian Sciences of Ukraine \\ ${ }^{3}$ The V.M. Remeslo Myronivka institute of wheat National Academy of Agrarian Sciences of \\ Ukraine
}

We focus on the food and forage value of a relatively new crop - triticale, as well as on the peculiarities of the creation of new cultivar Myronosets (originators: VM Remeslo Myronivka Institute of Wheat and Institute of Horticulture NAAS of Ukraine). Bioecological features and morphological characteristics of the new cultivar are presented, its grain yield and quality are characterized; quantitative data on the dough and bread qualities are summarized. The new triticale cultivar is compared with the best cultivars in terms of yield capacity, lodging resistance, in-spike germination and resistance to fungal diseases and unfavorable abiotic environmental factors. We analyzed the data of the state cultivar trials of Myronosets in 2019-2020. It was shown that this cultivar was lodging resistant, had high protein content and gave a high grain yield in the woodlands and Forest-Steppe of Ukraine. It was established that Myronosets was a source of the short stem. Hybridological analysis showed that in the hybrid combinations derived from Myronosets the plant height was inherited by different types. Negative overdominance (depression) was observed in $41.18 \%$ of the hybrid combinations under investigation; partial negative inheritance - in $23.53 \%$; intermediate inheritance - in $17.65 \%$; and partial positive dominance - in $17.65 \%$. There were high levels of hypothetical $(\mathrm{Ht}, \%)$ and true heterosis $(\mathrm{Hbt}, \%)$ in the following combinations: T 14-1 × LCh/97 (-22.32 and -31.4, respectively); Urahan $\times$ LCh/97 (-16.95 and 37.1, respectively); Kornet $\times \mathrm{LCh} / 97$ (-23.28 and -31.0 , respectively); Kharroza $\times \mathrm{LCh} / 97$ ( -8.78 and -16.6 , respectively). The Myronosets genotype possesses the wheat gene $R h t-B 1 b$, and it is assumed that the genotype of the new triticale cultivar carries the most convenient and significant for breeding dominant rye gene $H l(D d w 1)$, which determines the short stem and is a homologue of the wheat dwarfism gene Rht12. This was confirmed by significant changes in the phenotype of $\mathrm{F}_{1}$ hybrids, indicating that this gene has a wide pleiotropic effect: spike elongation, the increased numbers of flowers and grains in the main spike, a powerful root system, increased tillering coefficient, increased leaf area, etc. Therefore, we recommend including the new cultivar in breeding programs to create short-stemmed triticale cultivars that can avoid lodging, in particular when increased doses of nitrogen fertilizers are applied. In the article, we highlight that the new cultivar has other economically valuable characteristics, in particular, high lodging resistance ( 9 points), high shedding resistance ( 9 points), low spike brashness ( 9 points), resistance to in-spike germination (9 points), complex resistance to Puccinia recondita f. sp. tritici Rob. ex Desm (8.5 points), Blumeria graminis (DC.) Speer (9 points.), and Fusarium graminearum Schwabe (8.5 points), high resistance to the pest Mayetiola destructor Say (8.5 points), high frost tolerance and winter hardiness ( 9 points), high drought resistance (8.5-9 points). It is noteworthy that about $70 \%$ of plants survive the laboratory freezing (critical freezing temperature $-18.3^{\circ} \mathrm{C}$ ). The cultivar is resistant to spring and autumn frosts ( 9 points). The potential yield is $>7.5 \mathrm{t} / \mathrm{ha}$. The average yield

(C) V.V. Moskalets, V.I. Moskalets, T.Z. Moskalets, I.V. Grynyk, A.A. Demidov, S.I. Voloshchuk, S.O.

Khomenko. 2021.

ISSN 1026-9959. Селекція і насінництво. 2021. Випуск 119 
is $5.7 \mathrm{t} / \mathrm{ha}$ in the forest-steppe - woodlands transition belt, $6.3 \mathrm{t} / \mathrm{ha}$ in the central forest-steppe, and $3.5 \mathrm{t} / \mathrm{ha}$ in the woodlands.

Ke ywords: hexaploid winter triticale, new cultivar, agroecological and economic characteristics, donor of the short stem.

Introduction. Triticale is a relatively new agricultural crop that combines the economically valuable characteristics of wheat and rye, has a number of potential benefits that have not yet been fully explored, as the multi-year breeding practice has not fully "polished diamond from graphite", the value of which, given the global climate fluctuations, will be in earnest realized by future generations, in particular in overcoming food and feed challenges. Therefore, the creation of new cultivars and hybrids always forces to resort to certain improvisational principles of selection of parent pairs for hybridization. Today, the main efforts in triticale breeding are aimed at improving bread-making qualities, including protein content, composition of essential amino acids, falling number, yield capacity, tolerance to high soil acidity and drought, resistance to phytopathogens, bacterial and viral diseases [1-6]. It is breeding for adaptability that allows successful combining consistently high yields, resistance to diseases and pests, and tolerance to major limiting environmental factors in one genotype.

Thus, the creation of new triticale genotypes, the potentials of which to some extent would meet the scientific and industrial needs will never lose its relevance.

Literature review and problem articulation. Scientific results on triticale have a long history, which is confirmed by significant achievements in plant biology, breeding and genetics [721]. Recent data [22] prove that nothogenus $\times$ Triticosecale Wittmack ex A. Camus, 1927, belongs to the family Poaceae Barnhart, 1895, and includes the following species:

$\times$ Triticosecale neoblaringhemii (A. Camus) Mackey, $2005(2 \mathrm{n}=6 \mathrm{x}=42$; AABBDD) [23, 24], or Blaringhem's hexaploid triticale, which originates from Secale cereale $\times$ Triticum turgidum crossing;

$\times$ Triticosecale rimpaui (M.Graebn.) Wittmack ex A.W.Hill, $1933(2 \mathrm{n}=8 \mathrm{x}=56$; AABBDDRR) [25], or Rimpau's octoploid triticale, which originated from $S$. cereale $\times$ T. aestivum crossing;

$\times$ Triticosecale semisecale (Mac Key) K.Hammer \& A.Filatenko, $2010(2 \mathrm{n}=4 \mathrm{x}=28$; AABB) [26]. or semi-rye triticale, which, as VM Mezhensky noted [27], was originally created by $T$. monococcum $\times S$. cereale crossing and, basing on his literature review, the researcher assumed other possible ways of this species origination. A lot of researchers pointed out that hexaploid triticale was more productive [7-11].

The current areal of this crop covers 5 continents (Fig. 1).

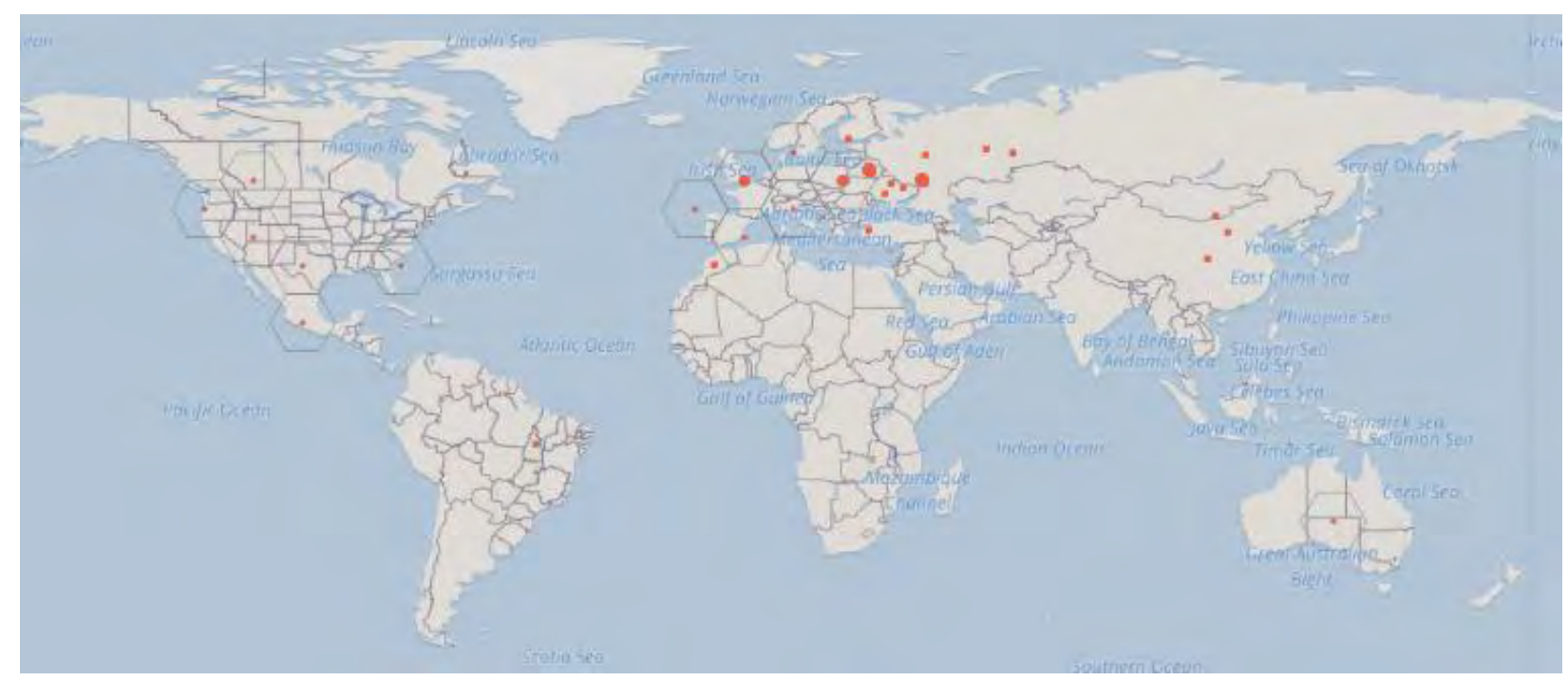

Fig. 1. The triticale areal in the world (as of 2019) [28] 
The global climate changes require reassessments of the sown area structure and of species and cultivar diversity of winter crops. It is winter crops, including triticale, have become a leading link in sustainable food production, as they have the highest yield potentials with genetic resistance to environmental limiting factors of a given region, pests and pathogens, which is of paramount importance in adaptive agriculture. Target-focused introduction of specific cultivars is another way to regulate the grain productivity of triticale. Therefore, due regard for the peculiarities of soil and climatic conditions of a given region upon introduction of one or another cultivar will enable complete fulfillment of its biopotential in terms of grain yield and quality.

Purpose and objectives - to create a new productive and high-protein cultivar of winter triticale, adapted to the woodlands/forest-steppe and forest-steppe of Ukraine.

Material and methods. The breeding work to create a new cultivar of triticale was continued at the Educational and Research Center of Bila Tserkva National Agrarian University in 2007-2017. The control and environmental trials were conducted in 2009-2019 in the woodlands (Polissya Institute of Agriculture NAAS (2007-2009); predecessor: seeded fallow), central foreststeppe (VM Remeslo Myronivska Institute of Wheat NAAS (2016-2019); forecrops: mustard, soybean, pea for seeds; Bila Tserkva NAU (2009-2016); predecessors: seeded fallow, potato), and northern Forest-Steppe (Institute of Horticulture NAAS (2016-2017); forecrop: perennial grasses). No plant protection measures were taken. The starting material was domestic and foreign triticale cultivars of different eco-geographical origin: Slavetne (UA), Pshenychne (UA), Chaian (UA), DAU 5 (UA), Urahan (UA), Ladne (UA), Rarytet (UA), Kharroza (UA), Poliske 7 (UA), Adas (BLR), Woltario (POL), Utro (BLR), Pigmei (POL), Triticale 64 (HUG), Kandar (SVK), Gorun 1 (ROM), Haduk (ROM, Prader (SV), AD 1668 (RU), PRAO 19 (RU), Kornet (RU) and others provided under negotiated agreement by the NCPGRU of the PPI nd.a. VYa Yuriev NAAS. Hybridization was performed by manual emasculation of female components. Plants were pollinated by the twirl method 2-3 days after emasculation. The breeding material was studied in compliance with the guidelines of the All-Union Research Institute of Plant Breeding [29] and the methodology of the State cultivar trials [30]. Data were statistically processed, as B.A. Dospekhov described [31], using Statistica-5.5 and Excel-2003 software.

Results and discussion. The joint work of Bila Tserkva National Agrarian University and Nosivka Breeding Research Station of the VM Remeslo Myronivka Institute of Wheat NAAS in 2008 in interspecific hybridization within the notogenus $\times$ Triticosecale and double individual selection from $\mathrm{F}_{2}-\mathrm{F}_{4}$ hybrid populations derived from crossing ( + Avhusto $\mathrm{x} \overbrace{}^{\top}$ Yahuar) $\mathrm{x}{ }^{\lambda} \mathrm{K} 9844 / 93$ followed by repeated improving selections in $\mathrm{F}_{10}$ allowed us to distinguish the best line, LCh97, which was later named as cultivar Myronosets. The new genotype is hexaploid, belongs to the erythrospermum variety. As to the growing period, it is mid-late (the growing period is 296 days). As to the growth habit, it is a winter cultivar. The identifying traits of this genotype are as follows: a sprawling bush, moderate anthocyanin pigmentation of coleoptiles and leaves, dark green leaves, a wide flag leaf, no anthocyanin pigmentation of spikes, wax bloom on the flag leaf sheath, anthocyanin pigmentation of awns; the flag leaf blade length is medium $(16.7 \mathrm{~cm})$, its width is medium $(1.8 \mathrm{~cm})$; the second leaf length is $26.4 \mathrm{~cm}$, its width is $1.5 \mathrm{~cm}$; no bluish wax bloom on spikes (Fig. 2).

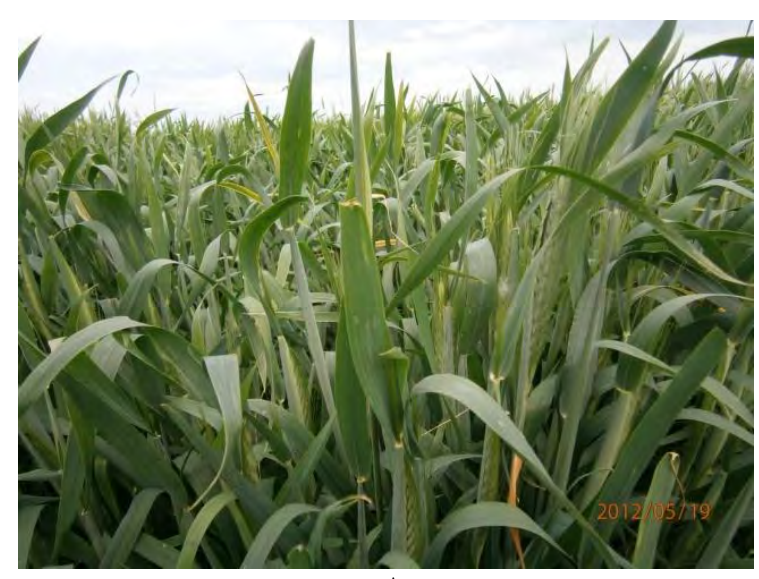

A

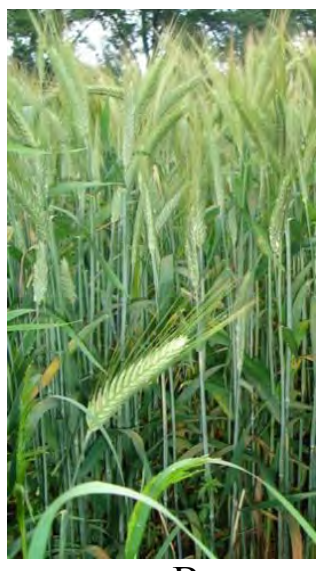

$\mathrm{B}$

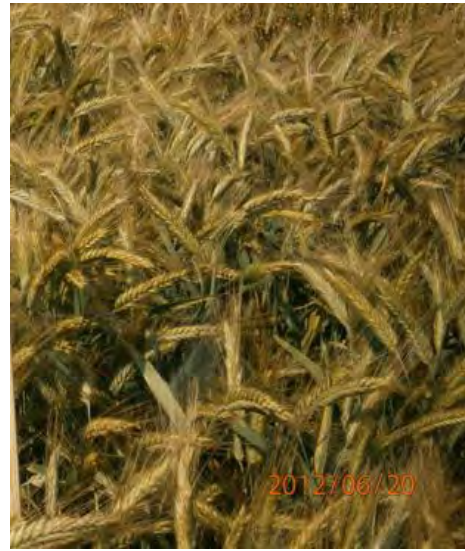

$\mathrm{C}$

Fig. 2. Plants of the $\mathrm{LCh} / 97$ line - different phases of development: A - earing onset; B - milky ripeness onset; $B$ - milky-wax ripeness 
The stem pubescence intensity below the spike is moderate. The plant is mid-tall $(94.8 \mathrm{~cm}$, low stems). There are awns are along the entire length of the spike; awns are long relative to the spike; the length of the keel tooth of the lower glume is $9-13 \mathrm{~mm}$; the second tooth of the lower glume is absent; the lower glume keel is distinct to its base; there is no pubescence of the outer surface of the lower glume; the spike is red and dense; the spike length without awns is medium $(13.4 \mathrm{~cm})$; the spike width is medium $(1.6 \mathrm{~cm})$; the spike is pyramid-shaped (Fig. 2); the straw is hollow in cross section and is strong without a zigzag below the spike. The average number of flowers per spike is $3-4$, and, as a rule, three of them are fertile. The caryopsis is elongated, light brown, slightly wrinkled, and medium in size. The 1000 -grainsweight is $45.7 \mathrm{~g}$; the test weight is $688.5 \mathrm{~g} / \mathrm{L}$.

The LCh/97 line was distinguished due to its performance, high lodging, and shedding resistance, low spike brashness, resistance to in-spike germination, complex resistance to $P$. recondita f. sp. tritici Rob. ex Desm, B. graminis (DC.) Speer, and F. graminearum Schwabe, high resistance to the pest Mayetiola destructor Say, high frost tolerance and winter hardiness, drought resistance (8.5-9 points), about 70\% survival after freezing in the laboratory (critical freezing temperature $\left.-18.3^{\circ} \mathrm{C}\right)$, resistance to spring and autumn frosts (9 points) and potential yields of over $7.5 \mathrm{t} / \mathrm{ha}$, with the average grain yields of $5.7 \mathrm{t} / \mathrm{ha},>6 \mathrm{t} / \mathrm{ha}$ and $>3 \mathrm{t} / \mathrm{ha}$ in the Forest-Steppe Woodlands transition belt, central Forest-Steppe and Woodlands, respectively (Fig. 3).
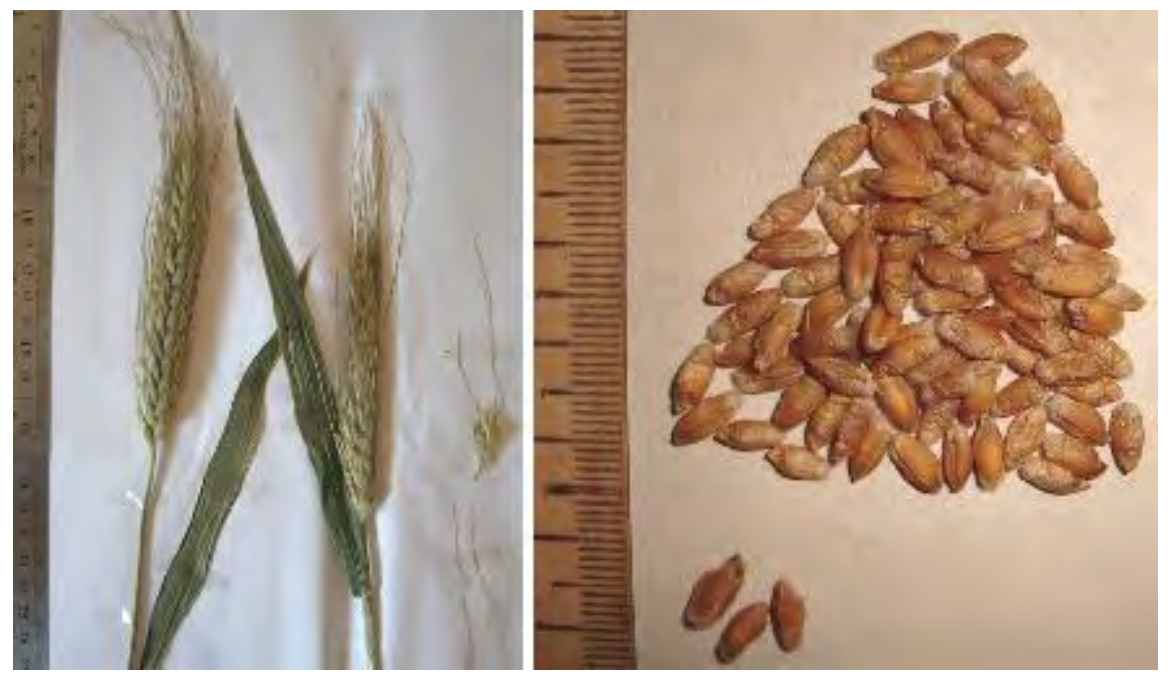

\section{Fig. 3. Spike, spike parts and caryopsis of the winter triticale line $\mathrm{LCh} / 97$}

Trials of the new cultivar showed that the spikelet number per spike and the grains number in the main spike in the cultivar of Myronosets are comparable to those in the best varieties (Ladne, AD 256, Dorena, Slavetne, etc.). There is a significant difference in the spike density (28.5 spikelets per $10 \mathrm{~cm}$ of spike), indicating that the cultivar has a denser spike, with a better harvest index.

In the central Forest-Steppe, if seeds were sown at a recommended seeding rate (4.5 million seeds/ha) within the optimal timeframe, shoots are even. It should be noted that the lower (by $3-5^{\circ}$ ) air temperature during germination related to the optimum, the deeper the tillering node is located, and, due to this, strong primary shoots and later strong secondary shoots appear. In turn, the tillering node forms its root tier, resulting in a larger mass of the root system, and more powerful root system is more able to provide the plant with the necessary reserve to adapt to the winterspring period. On average for 2008-2016, the $\mathrm{LCh} / 97$ line gave a yield of $5.33 \mathrm{t} / \mathrm{ha}$, which is 0.23 t/ha less than that from AD 256 (Fig. 4). It was found that the high grain productivity of the LCh/97 line was attributed to the increased number of productive stems per $1 \mathrm{~m}^{2}$ (523 stems), the high number of grains per spike, etc. 


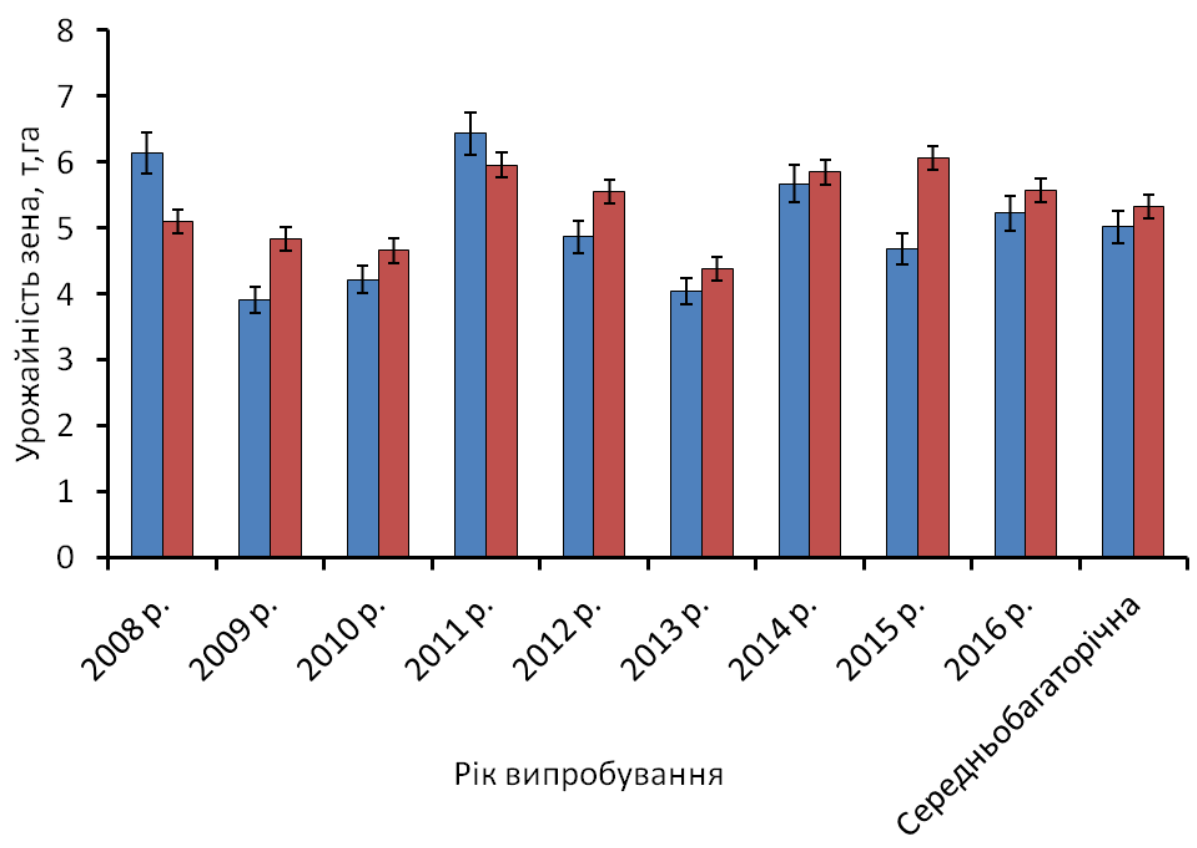

АД $256 \square$ Мироносець

Fig. 4. Grain yield from the winter triticale line $\mathbf{L C h} / 97$ in the central forest-steppe over the years

The optimal seeding depth for the new cultivar sown in light loamy chernozem of the foreststeppe is 3-4 cm; in sod-podzolic sandy-loam soil $-5-6 \mathrm{~cm}$; due to drought the seeding depth should be increased by $1.5-2 \mathrm{~cm}$. Rolling should be carried out with a star-wheeled roller KKSh- 6 before and after sowing. In 2008 and 2009, the seeding depth was 6-7 cm, and under the arid conditions during the autumn periods of these years, $\mathrm{LCh} / 97$ plants formed shoots from dormant buds of the embryonic node during the growing period, and after the first shoot appearance secondary and tertiary shoots emerge, indicating a high adaptability to unfavorable conditions, including water deficit in soil. This feature is also important when rapid production of seeds is needed. In addition, it is important for competition with weeds and "autumn" pests, resistance to anomalies during the winter-spring period, and, most important, for a high yield of grain, mainly due to lateral shoots.

The results of the study conducted in the experimental field of the Educational and Resrarh Center of Bila Tserkva NAU (forest-steppe) showed that if seeds were sown within the optimal timeframe (September 20-25), 2 productive and 3-4 unproductive stems appeared, and the grain yield from the new cultivar increased by $25 \%$. When sown later, plants had 1 productive stem and 5-6 unproductive ones, which account for up to $45 \%$ of the grain yield. Similar findings were noted by other researchers. It was also found that the $\mathrm{LCh} / 97$ fields were able to get rid of extra shoots under the influence of extreme biotic and abiotic factors, leaving 3-4 (sometimes 1-2) fruiting stems, often 1-3 stems with underdeveloped spikes and 1-2 unfertile stems without spikes, which form a radical rosette.

In the Woodlands/Forest-Steppe zone (Nosivka Breeding Research Station of Myronivka Institute of Wheat NAAS), the LCh/97 line gave an average grain yield of $4.8 \mathrm{t} / \mathrm{ha}$ and was noticeable for complex field resistance to powdery mildew, speckled leaf blotch, brown rust, and head blight ( $8-9$ points).

In the framework of scientific cooperation with the Plant Production Institute named after V.Ya. Yuriev NAAS, we managed to find out that the total vitreousness the LCh/97 grain was 10\%; the protein content $-12.9 \%$; the crude gluten content $-27.9 \%$; the dough resilience $(\mathrm{P})-52 \mathrm{~mm}$; the dough extensibility $(\mathrm{L})-47 \mathrm{~mm}$; the $\mathrm{P} / \mathrm{L}$ ratio -1.1 ; the flour strength $(\mathrm{W})-92$; the elasticity index (Le) $-33 \%$; the loaf volume $-392 \mathrm{~mL}$ per $100 \mathrm{~g}$ of flour. The scores of bread made from flour of this line were as follows (in points): surface - 5; shape - 3; crust color -5 ; the total score 5 (Fig. 5). 


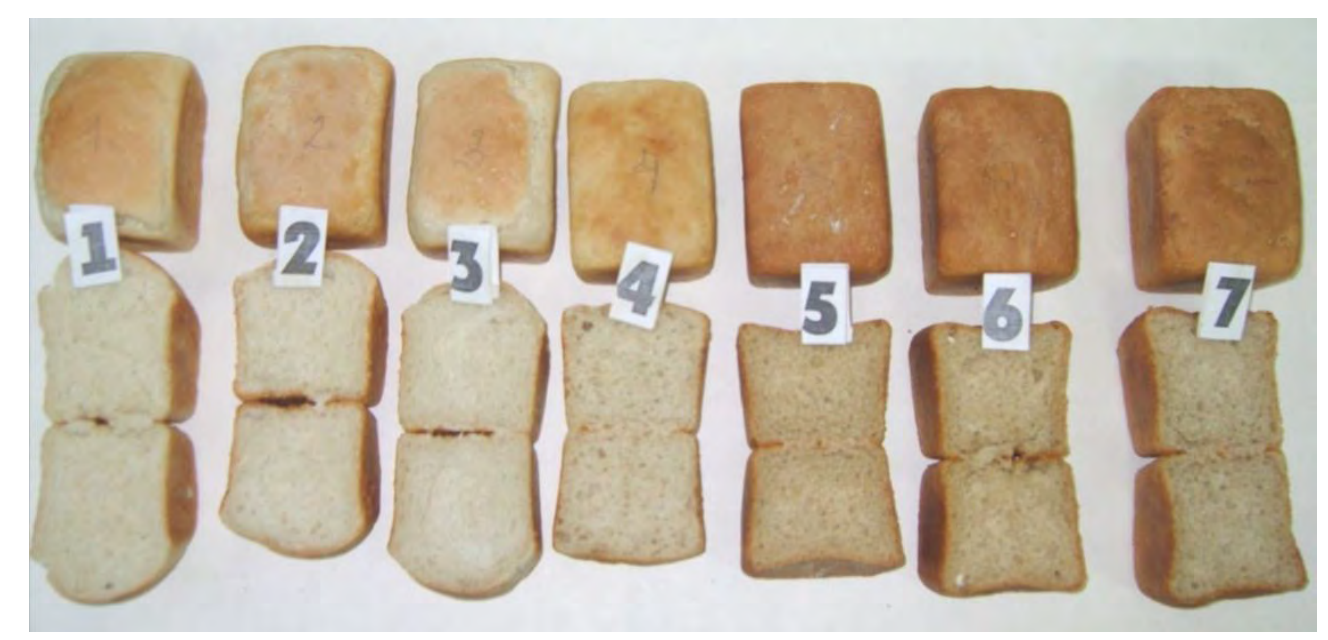

Fig. 5. Appearance of bread from winter triticale cultivars and lines: 1 - Vivate Nosivske; 2 - Slavetne; 3 - Slavetne; 4 - Strateh; 5 - LCh/97; 6 - Pshenychne; 7 - Karlyk

The crumb porosity in bread from the LCh/97 line was 5 points; the crumb color score -3 points; the crumb elasticity score -5 points, and the total bread-making score -4.9 points (Table 1).

Table 1

The quality indicators of grain, dough and bread from winter triticale cultivars and lines

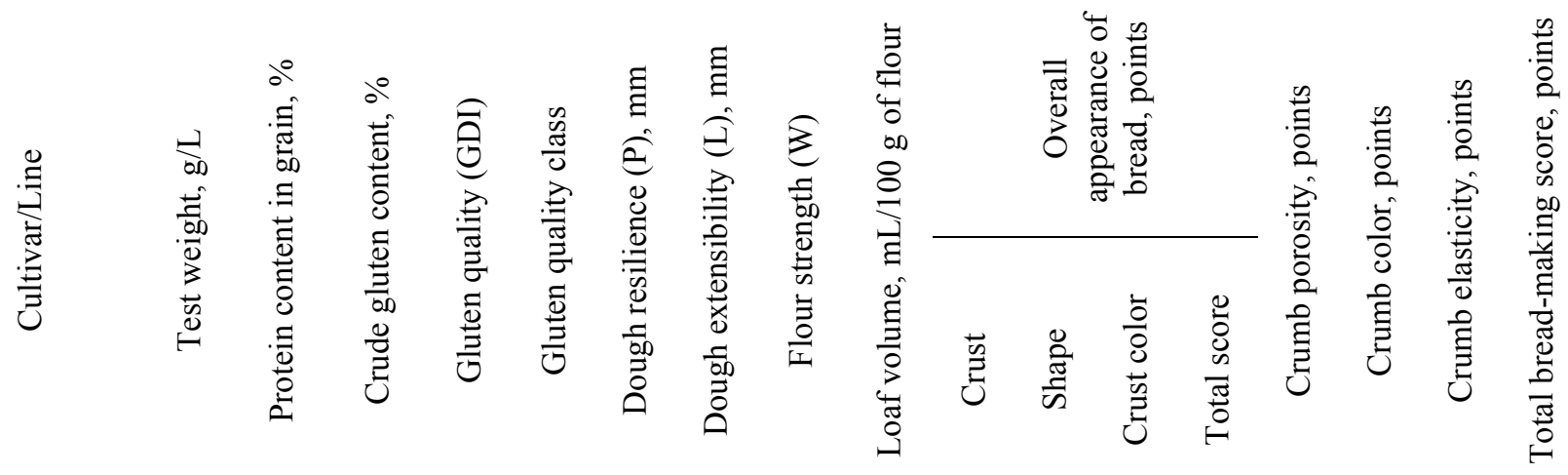

\begin{tabular}{cccccccccccccccccc}
\hline Vivate & 712 & 10.9 & 24.5 & 85 & II & 69 & 19 & 76 & 480 & 9 & 9 & 9 & 9 & 9 & 9 & 9 & 9.0 \\
Nosivske & & & & & & & & & & & & & & & & & \\
Slavetne & 716 & 11.7 & 21.5 & 95 & II & 65 & 24 & 72 & 430 & 5 & 9 & 7 & 7 & 9 & 9 & 9 & 8.6 \\
Slavetne & 718 & 11.5 & 20.1 & 94 & II & 55 & 34 & 72 & 460 & 9 & 9 & 9 & 9 & 9 & 7 & 7 & 8.2 \\
Strateh & 710 & 10.6 & 24.5 & 120 & III & 48 & 25 & 46 & 390 & 5 & 7 & 7 & 6.8 & 5 & 7 & 5 & 6.1 \\
LCh/97 & 612 & 13.2 & 27.5 & 119 & III & 52 & 47 & 92 & 392 & 5 & 3 & 5 & 4.3 & 5 & 3 & 5 & 4.9 \\
Pshenychne & 644 & 11.2 & 23.8 & 84 & II & 71 & 22 & 81 & 410 & 5 & 5 & 5 & 5 & 5 & 3 & 5 & 5.4 \\
Karlyk & 708 & 10.2 & 20.5 & 118 & III & 59 & 43 & 111 & 440 & 5 & 7 & 7 & 6.3 & 5 & 5 & 5 & 6.1 \\
\hline
\end{tabular}

Table 1 shows that the $\mathrm{LCh} / 97$ line is superior to the other accessions in tens of protein and gluten contents in grain (for example, Slavetne and Strateh): the difference is 14.8-24.5 and 12.2$34.1 \%$, respectively, although it is inferior to them in terms of the dough and bread qualities.

The study conducted in the northern Forest-Steppe of Ukraine demonstrated that the new triticale cultivar of Myronosets was responsive to high doses of mineral fertilizers and gave high grain yield $(+10-45 \%$ compared to other triticale and rye cultivars, depending on sowing rime) (Table 2). 
Table 2

The grain yield from Myronosets in comparison with other triticale, rye and wheat cultivars, $\mathbf{g} / \mathbf{m}^{2}$, northern Forest-Steppe (Institute of Horticulture NAAS), average for $2017-2020$

\begin{tabular}{|c|c|c|c|c|c|c|}
\hline \multirow[b]{2}{*}{ Sowing time } & \multirow[b]{2}{*}{ Cultivar } & \multicolumn{5}{|c|}{ Treatment } \\
\hline & & $\begin{array}{l}\text { Without fertilizers } \\
\text { (control) }\end{array}$ & $(\mathrm{NPK})_{30}$ & $(\mathrm{NPK})_{60}$ & $(\mathrm{NPK})_{90}$ & $(\mathrm{NPK})_{120}$ \\
\hline \multirow{7}{*}{20 September } & AD 256 & 961.5 & 1110.3 & 1096.5 & 1184.7 & 703.5 \\
\hline & Myronosets & 788.3 & 839.7 & 1315.1 & 1446.6 & 1607.2 \\
\hline & Slavetne & 880.7 & 994.5 & 1106.7 & 1744.1 & 421.8 \\
\hline & Borotba* & 482.5 & 652.9 & 722.6 & 915.5 & 612.7 \\
\hline & Yuvivata $60^{* *}$ & 345.0 & 375.6 & 403.5 & 747.3 & 851.5 \\
\hline & Smuhlianka** & 412.6 & 545.8 & 488.0 & 823.9 & 814.4 \\
\hline & $L S D_{05}$ & 63.2 & 70.0 & 79.6 & 112.6 & 77.7 \\
\hline \multirow{7}{*}{30 September } & AD 256 & 664.6 & 920.5 & 961.6 & 1276.2 & 913.6 \\
\hline & Myronosets & 601.5 & 783.2 & 1065.0 & 1295.0 & 1694.1 \\
\hline & Slavetne & 717.5 & 1022.7 & 1007.4 & 1065.3 & 637.4 \\
\hline & Borotba* & 629.7 & 638.3 & 942.7 & 891.5 & 711.8 \\
\hline & Yuvivata $60 * *$ & 440.1 & 465.9 & 718.1 & 955.0 & 1063.2 \\
\hline & Smuhlianka** & 356.4 & 378.5 & 491.8 & 563.3 & 934.7 \\
\hline & $L S D_{05}$ & 52.8 & 65.2 & 80.4 & 93.8 & 92.3 \\
\hline \multirow{7}{*}{10 October } & AD 256 & 572.5 & 714.9 & 840.3 & 1128.6 & 817.3 \\
\hline & Myronosets & 475.4 & 656.8 & 687.5 & 865.9 & 1055.3 \\
\hline & Slavetne & 471.5 & 662.2 & 909.0 & 833.5 & 761.0 \\
\hline & Borotba* & 450.3 & 656.7 & 597.9 & 840.1 & 659.4 \\
\hline & Yuvivata $60 * *$ & 510.0 & 527.4 & 659.5 & 693.2 & 711.7 \\
\hline & Smuhlianka** & 493.5 & 467.2 & 536.4 & 579.6 & 623.0 \\
\hline & $L S D_{05}$ & 46.1 & 57.1 & 71.8 & 76.6 & 71.8 \\
\hline
\end{tabular}

In 2016-2017, within the framework of the agreement on joint scientific cooperation between Bila Tserkva NAU, V.M. Remeslo Myronivka Institute of Wheat of NAAS and the Institute of Horticulture of NAAS, the winter triticale line LCh/97 (as a prototype cultivar Myronosets) passed a variety pre-trial in the central and northern Forest-Steppe. Positive results in 2017 gave grounds to submit it (under the name of Myronosets) to the State variety trials (Application No 17022009 dated 21/12/2017). The authors of the cultivar: Demydov OA, Hrynyk IV, Moskalets VI, Moskalets VM, Khomenko SO, Siroshtan AA, Voloshchuk SI, Moskalets TZ, Moskalets VV. The owners of the cultivar: VM Remeslo Myronivka Institute of Wheat of NAAS of Ukraine and the Institute of Horticulture of NAAS of Ukraine.

The results of the 2019 trial (letter of the Ukrainian Institute of Plant Variety Examination No 45-3-10-3/1587 dated 18/09/19 to the V.M. Remeslo Myronivka Institute of Wheat of NAAS) showed that the yield from Myronosets exceeded the average yield from the cultivars that had passed the state registration within the previous 5 years in the Forest-Steppe and Woodlands by $0.44 \mathrm{t} / \mathrm{ha}$ and $0.67 \mathrm{t} / \mathrm{ha}$, respectively.

The results of the 2020 trial (letter of the Ukrainian Institute of Plant Variety Examination No 45-3-10-2/2592 dated 11/09/20 to the V.M. Remeslo Myronivka Institute of Wheat of NAAS) demonstrated that the yield from this cultivar exceeded the average yield by $0.2 \mathrm{t} / \mathrm{ha}$ in the Woodlands.

Analyzing the yield data obtained in the 2019-2020 State variety trials, we found that the yield from Myronosets was higher than the average yield from the cultivars that had passed the state registration within the previous 5 years in the Forest-Steppe and Woodlands: in the Chernihivska 
Oblast - by 0.77 t/ha, in the Rivnenska Oblast - by $0.41 \mathrm{t} /$ ha, in the Volynska Oblast - by $0.1 \mathrm{t} / \mathrm{ha}$, in the Ivano-Frankivskska Oblast $-0.64 \mathrm{t} / \mathrm{ha}$, in the Ternopilska Oblast - by $2.6 \mathrm{t} / \mathrm{ha}$, and in the Sumska Oblast - by 0.75 t/ha (Fig. 6).

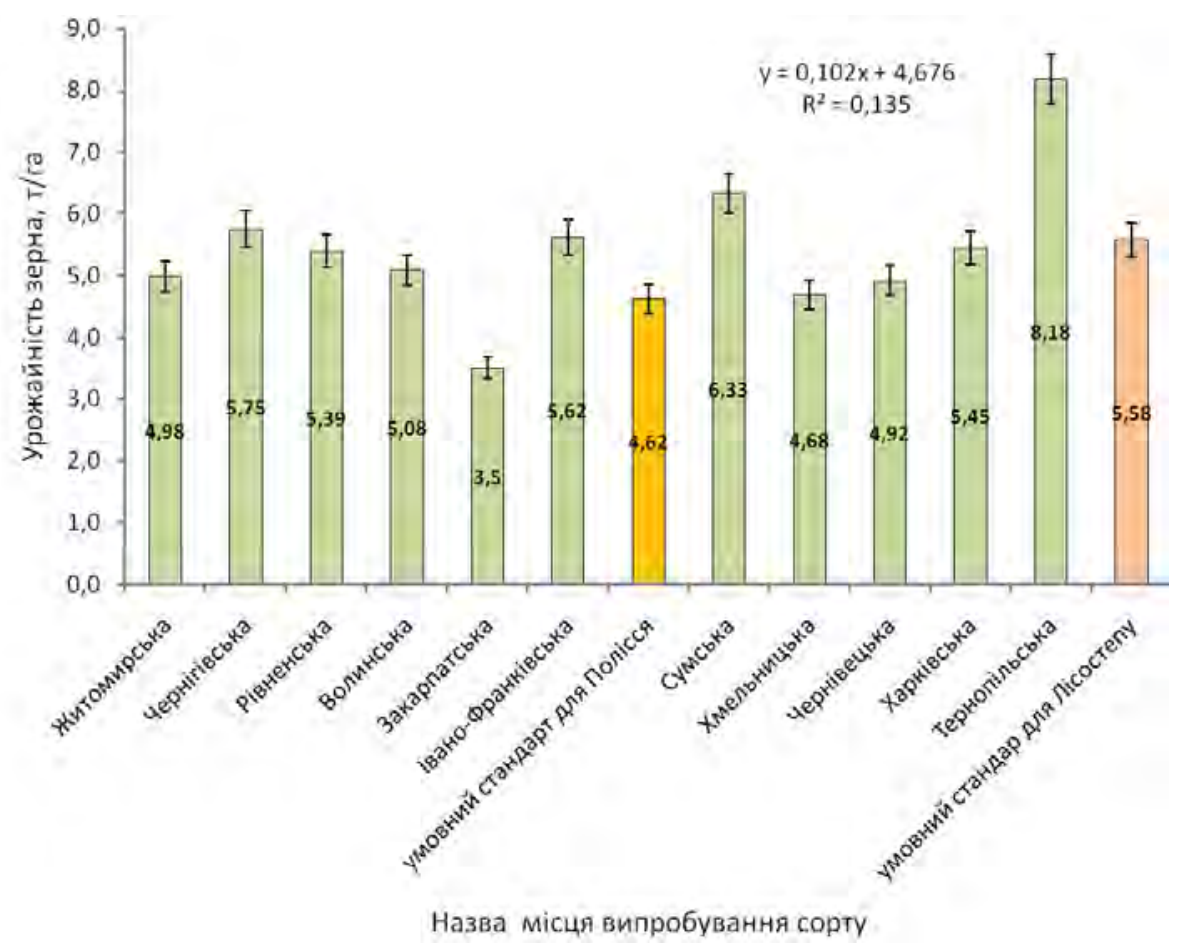

Fig. 6. The average grain yield from winter triticale Myronosets in the Oblasts of Ukraine based on the results of the state variety trials in 2019-2020: conditional check cultivars for the Woodlands and Forest-Steppe (orange and pink columns in the picture) - the yields from the cultivars that had passed the state registration within the previous 5 years in the Forest-Steppe and Woodlands based on the results of the state variety trials

It should be noted that Myronosets was highly resistant to lodging; the average plant height was $94.4 \mathrm{~cm}$ and 95.4 in the Forest-Steppe and Woodlands of Ukraine, respectively; the range across the country was $81.5-110.5 \mathrm{~cm}$ (Fig. 7).

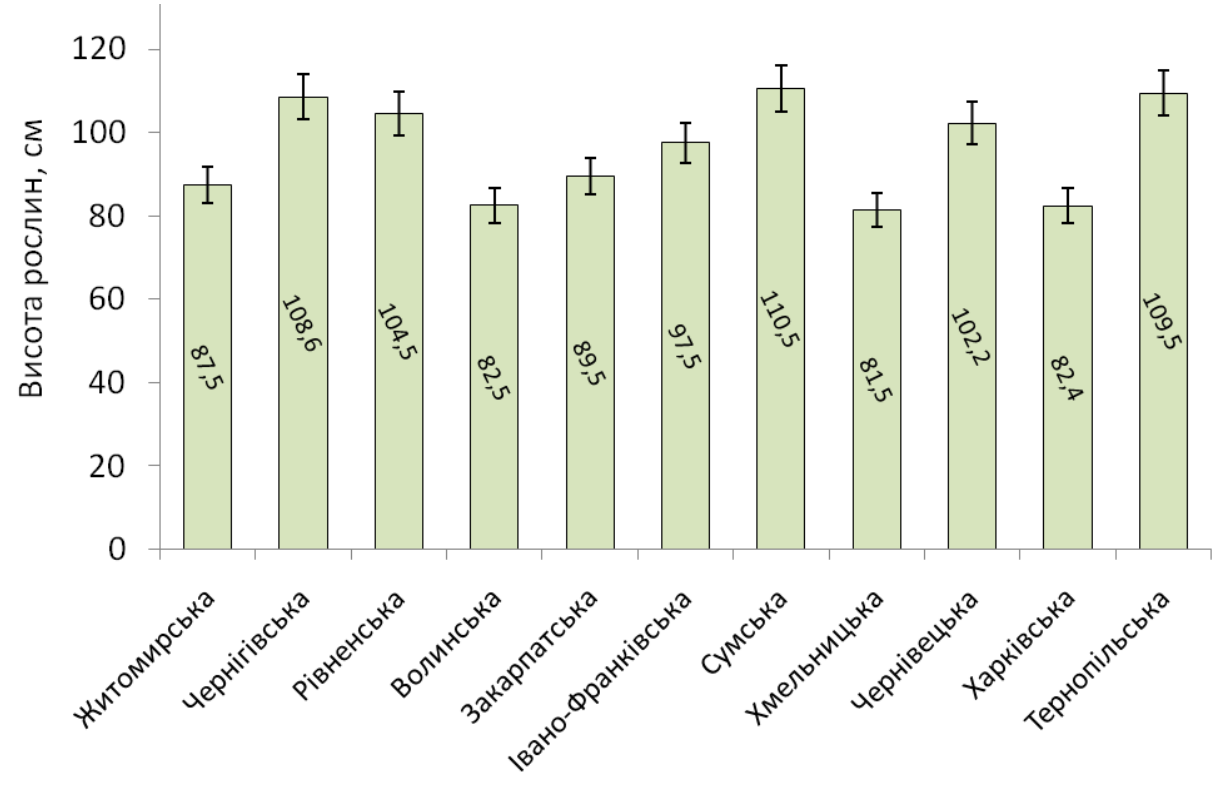

Назван місця випробування сорту

Fig. 7. The average height of winter triticale Myronosets plants in the Oblasts of the country, results of the 2019-2020 state variety trials 
Analysis of the state variety trial data showed that in the woodlands the protein content in Myronosets grain fluctuated within 12.7\% in 2019 (Chernihivska and Ivano-Frankivskska Oblasts), $14.3 \%$ (Rivnenska Oblast) and 14.9\% (Zhytomyrska Oblast). In the Forest-Steppe this parameter fluctuated within 10.8\% (Khmelnytska Oblast), 11.2\% (Kharkivska Oblast), 13.1\% (Chernihivska Oblast) and 14.9\% (Sumska Oblast). In 2020 in the Woodlands - 12.2\% (Zhytomyrska Oblast), 12.3\% (Ivano-Frankivska Oblast), 13.7\% (Zakarpatska Oblast), and 14.1\% (Chernihivska Oblast); in the Forest-Steppe $-9.2 \%$ (Kharkivska Oblast), 10.7\% (Chernivetska Oblast), 13.5\% (Khmelnytska Oblast), and 16.1\% (Sumska Oblast) (Fig. 8).

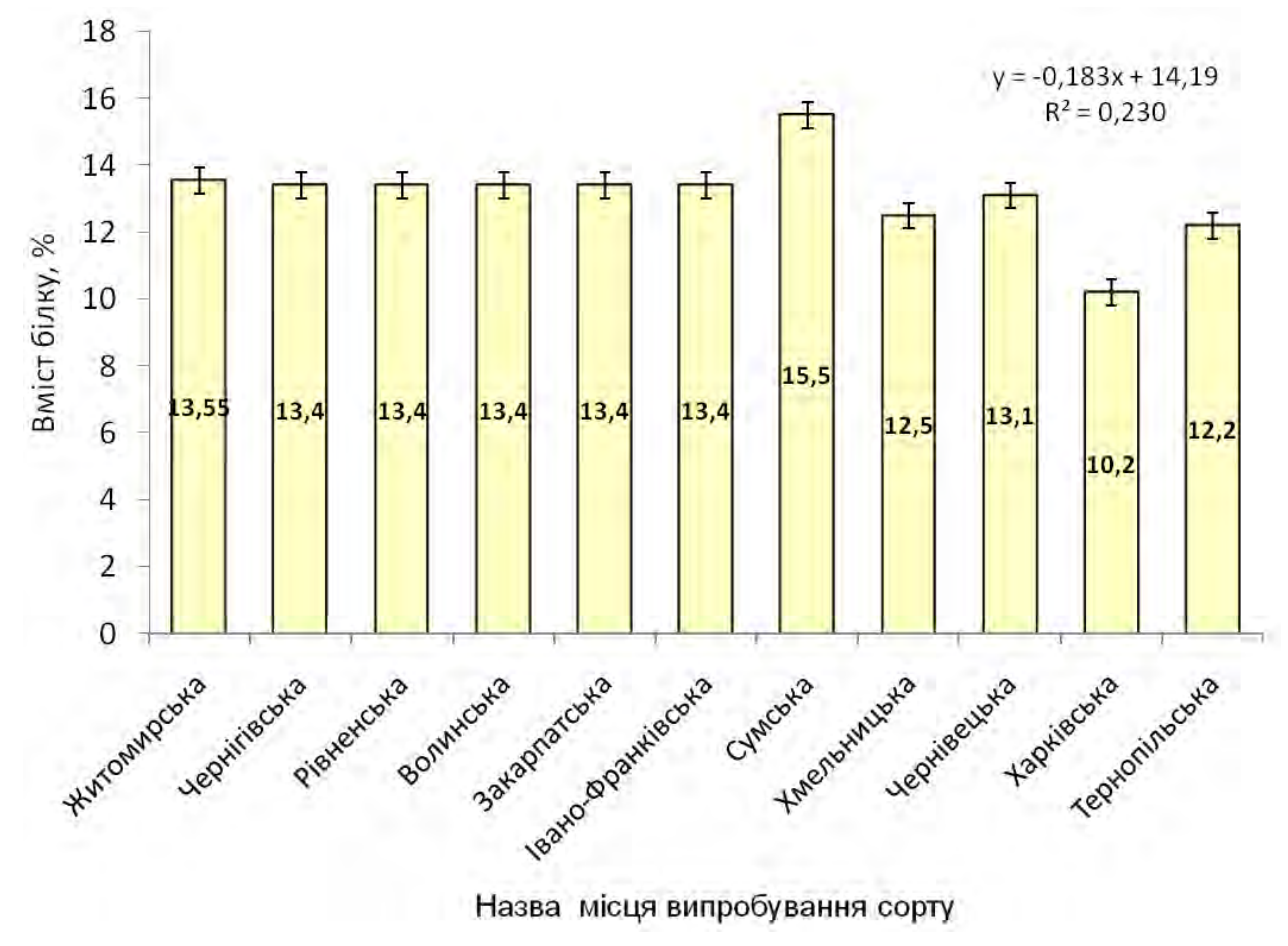

Fig. 8. The average protein content in winter triticale Myronosets grain in the Oblasts of the country based on the results of the state variety trials in 2019-2020

The data indicate that winter triticale Myronosets is a mid-protein cultivar.

In 2021, Myronosets was included in the State Register of Plant Varieties suitable for cultivation in the Woodlands and Forest-Steppe of Ukraine [32].

It is known that to strengthen the competitiveness of triticale one cultivar has to combine high performance of plants, short stems, high bread-making scores, and complex resistance to unfavorable environmental factors [18]. In our opinion, this was achieved in Myronosets, which can serve as a model cultivar.

It should be noted that Myronosets is a source of the short stem. Hybridological analysis of populations obtained via hybridization in the northern Forest-Steppe (Institute of Horticulture NAAS) showed that in $F_{1}$ from crossing tall accessions with Myronosets (LCh/97) the "plant height" trait was depressed in comparison with the parents. However, different types of inheritance were observed in hybrid combinations originating from LCh/97. Negative overdominance (depression) was observed in $41.18 \%$ of all the combinations; partial negative inheritance - in $23.53 \%$; intermediate inheritance - in $17.65 \%$; and partial positive dominance - in $17.65 \%$. In 10 of the presented combinations (Table 3), high levels of hypothetical (Ht, \%) and true heterosis (Hbt, \%) were noted: T 14-1 $\times$ LCh/97 - -22.32 and -31.4; Hurricane $\times$ Champions League / $97--16.95$ and -37.1; Cornet $\times$ Champions League / $97--23.28$ and -31.0, respectively; Kharroza $\times$ LCh/97 -8.78 and -16.6 , respectively. Thus, the phenotypic changes in the traits in $\mathrm{F}_{1}$ hybrids indicate that at the genetic level, the values of the "plant height" trait predominate not only the additive type of gene interaction, but also others, which is seen as its negative dominance and overdominance. The average values of negative hypothetical and true heterosis (-7.0 and -15.1 , respectively), with a 
medium phenotypic dominance in the hybrid combinations (0.76) indicate the presence of recessive gene alleles reducing the plant height in the new genotype, Myronosets (or LCh/97 line) (Table 3).

Table 3

Degrees of heterosis and phenotypic dominance for the "plant height" trait in $F_{1}$ winter triticale hybrids derived from the $\mathrm{LCh} / 97$ line, 2017

\begin{tabular}{|c|c|c|c|c|c|c|c|c|}
\hline $\begin{array}{l}\text { Cultivar, line, hybrid } \\
\text { combination }\end{array}$ & $\mathrm{P} 1$ & $\mathrm{P} 2$ & $\mathrm{~F}_{1}$ & $\mathrm{Ht}, \%$ & $\mathrm{Hbt}, \%$ & hp* & MP & BP \\
\hline Rarytet $\times$ LCh/97 & 115.2 & 92.5 & 107.0 & 3.03 & -8.5 & 0.24 & 103.85 & 117.1 \\
\hline $\mathrm{T} 14-1 \times \mathrm{LCh} / 97$ & 107.6 & 92.5 & 75.5 & -22.32 & -31.4 & -2.47 & 100.05 & 110.0 \\
\hline Urahan $\times$ LCh $/ 97$ & 168.7 & 94.5 & 109.3 & -16.95 & -37.1 & -0.53 & 131.6 & 173.8 \\
\hline Polianske $\times$ LCh $/ 97$ & 100.3 & 91.8 & 92.1 & -4.11 & -9.3 & -0.72 & 96.05 & 101.5 \\
\hline Kornet× LCh /97 & 108.5 & 90.4 & 76.3 & -23.28 & -31.0 & -2.10 & 99.45 & 110.5 \\
\hline Atlet $\times$ LCh $/ 97$ & 105.7 & 91.5 & 80.5 & -18.36 & -25.1 & -2.03 & 98.6 & 107.5 \\
\hline Prader $\times$ LCh $/ 97$ & 90.7 & 94.3 & 102 & 10.27 & -0.5 & 0.95 & 92.5 & 102.5 \\
\hline Kandar $\times$ LCh $/ 97$ & 103.8 & 95.2 & 81.5 & -18.09 & -22.7 & -3.0 & 99.5 & 105.5 \\
\hline AD $1668 \times$ LCh $/ 97$ & 112.5 & 94.4 & 85.6 & -17.25 & -25.3 & -1.60 & 103.45 & 114.6 \\
\hline PRAO $19 \times$ LCh $/ 97$ & 110.7 & 93.9 & 110 & 7.53 & -4.9 & 0.57 & 102.3 & 115.7 \\
\hline Amur $\times$ LCh $/ 97$ & 95.5 & 93.5 & 80.5 & -14.81 & -17.7 & -4.24 & 94.5 & 97.8 \\
\hline Ticino $\times$ LCh $/ 97$ & 109.3 & 90.5 & 120 & 20.12 & -4.6 & 0.78 & 99.9 & 125.8 \\
\hline Kharroza $\times$ LCh $/ 97$ & 110.4 & 93.5 & 93 & -8.78 & -16.6 & -0.94 & 101.95 & 111.5 \\
\hline Slavetne $\times$ LCh $/ 97$ & 113.4 & 92.5 & 85.5 & -16.95 & -26.1 & -1.37 & 102.95 & 115.7 \\
\hline LCh $/ 97 \times$ Slavetne & 90.5 & 114.5 & 103.5 & 0.98 & 8.5 & -0.14 & 102.5 & 95.4 \\
\hline Pshenychne $\times$ LCh $/ 97$ & 99.7 & 92.5 & 95.6 & -0.52 & -6.7 & -0.08 & 96.1 & 102.5 \\
\hline LCh $/ 97 \times$ Pshenychne & 92.8 & 101.6 & 97.5 & 0.31 & 2.1 & -0.18 & 97.2 & 95.5 \\
\hline
\end{tabular}

* hp - degree of dominance; $\mathrm{F}_{1}$ - arithmetic mean for a $\mathrm{F}_{1}$ hybrid; $\mathrm{MP}$ - arithmetic mean for the both parents; $\mathrm{BP}$ - arithmetic mean of a parent with the maximum expression of the trait.

Previous studies indicate that the Myronosets genotype carries the wheat gene Rht-B1b [33], which causes a decrease in the plant height by $15-17 \%$ and increase in the yield by $\leq 20 \%$. It is known that the allele $R h t-B 1 b$ resulted from mutation of the wild-type allele Rht-B1a (which is an ortholog of the Arabidopsis GAI gene and encodes the DELLA protein, which consists of the Nterminal domain responsive to gibberellic acid (GA) and $\mathrm{C}$-terminal region functioning as a repressor [gene expression inhibitor] the GA signal) [34, 35]. One pair of nucleotides was replaced, and the stop codon TAG appeared downstream from the translation initiation site [35], resulting in the DELLA protein with a shortened N-terminus. This disrupts the GA-GID1-DELLA interaction and subsequent degradation of the DELLA protein [36]. In addition to wheat genes, we assume that the genotype of the new triticale cultivar carries the most convenient and important for breeding dominant the rye gene $H l(D d w l)$ determining the short stem, which is a homologue of the wheat gene Rht12 of dwarfness [37, 38], located on the long arm of chromosome 5R [39] and closely linked to the microsatellite locus REMS1218 discovered by Volodymyr Kobylianskyi in 1972 [40] in a natural mutant rye EM-1. Our assumption about the presence of the gene $\mathrm{Hl}$ in Myronosets was confirmed by significant changes in the phenotypes of $F_{1}$ hybrids. They indicate that this gene has a wide pleiotropic effect: an increased spike length, increased numbers of flowers and grains in the main spike, a strong root system, increased coefficient of tillering, increased leaf surface, etc. [40]. Therefore, the new cultivar is expedient to include in breeding for developing short-stemmed cultivars to prevent triticale lodging, in particular at high doses of nitrogen fertilizers.

It should be noted that a decrease in the height in hybrid plants was observed in reverse crosses. It is noteworthy that, when cultivars Polianske, AD 1668, Kandar, Kharroza, Slavetne, PRAO 19, etc. were crossed with the $\mathrm{LCh} / 97$ line, partial negative inheritance and negative dominance were observed for the traits of "spike length", "grain weight from the main spike", "grain number in the main spike","upper internode length", and "grain weight per plant". Therefore, 
to create new high-yielding and lodging resistant winter triticale cultivars, we recommend using Myronosets as a parent, as there is a high probability of selection of short-stemmed and productive accessions.

Therefore, to overcome the problem of tall triticale in breeding, Myronosets can be used in crossing as a parent or a donor (source of genetic material for recombination in the recipient genome). Hybrids originated from Myronosets had shortened stems, increased lodging resistance, increased number of flowers, spikelets and grains per spike, augmented pollen fertility, which, as it was reported in [41], occurs due to enhanced influx of assimilates during the spike formation.

In the future, we are planning to continue studying genes that regulate plant height in Myronosets, to develop molecular markers for their identification as well as to apply and validate these markers for hexaploid triticale.

Conclusions. The new triticale cultivar of Myronosets gives a high yield of over $7.5 \mathrm{t} / \mathrm{ha}$, is resistance to lodging, shedding, spike brashness, and in-spike germination, shows complex resistance to $P$. recondita f. sp. tritici Rob. ex Desm, B. graminis (DC.) Speer, and F. graminearum Schwabe, and to the pest Mayetiola destructor Say, highly frost tolerant, winter hardy, drought resistant (8.5-9 points). About $70 \%$ of plants survive after freezing in the laboratory at $-18.3^{\circ}$. The cultivar is also resistant to spring and autumn frosts ( 9 points). Myronosets plants are able to regulate their performance under the influence of unfavorable extreme bio- and abiotic factors.

The qualification examination showed that Myronosets was a mid-protein cultivar $(13.5 \%$ of protein in grain). The cultivar is recommended for growing in the Woodlands and Forest-Steppe. In addition, Myronosets is valuable for combination breeding as a source of the short stem.

\section{Список використаної літератури}

1. Гірко В.С., Гірко О.В., Волощук С.I. Вплив агрокліматичних умов на урожайність тритикале озимого та ефективність технології вирощування. 3б. наук. пр. ННЦ Інститут землеробства НААН. 2010. Вип. 4. С. 213-223.

2. Москалець B.B. Triticosecale Wittmack ex. A. Camus: екосистемний підхід дослідження для формування сталих урожаїв : монографія Донецьк : Ноулідж, 2014. 601 с.

3. Пикало С. В. Селекція in vitro тритикале на стійкість до абіотичних стресових чинників (огляд). Миронівський вісник. 2019. Вип. 9. С. 80-90. DOI: https://doi.org/10.31073/mvis.

4. Рибалка О.І., Моргун В.В., Моргун Б.В., Поліщук С.С. Генетичні основи нового напряму селекції оригінальних за якістю зерна класів пшениці (Triticum aestivum L.) і тритикале (х Triticosecale Wittmack). Фізіологія рослин і генетика. 2019. T. 51, № 3. C. 207-240. DOI: 10.15407/frg2019.03.207.

5. Moskalets V.V., Moskalets T.Z., Vasylkivskyi S.P. et al. Adaptability and stability mechanisms of Triticeae tribe to epiphytoparasites in anthropical ecosystem. Ukrainian Journal of Ecology. 2017. 7(2). P. 230-238.

6. Москалець Т. 3., Ключевич М.М., Москалець В.В.Стійкість озимих тритикале і пшениці м'якої проти Puccinia recondita Dietel\&Holw. Карантин $i$ захист рослин. 2015. № 6. С. 1-3.

7. Шулындин А.Ф. Тритикале - новая зерновая и кормовая культура. Киев: Урожай, 1981. 49 c.

8. Dogan R., Kacar O., Coplu N., Azkan N. Characteristics of new breeding lines of triticale. J. Agric. Res. 2009. № 4. P. 133-138.

9. Гриб С.И., Буштевич В.Н. Селекция тритикале в Беларуси: результаты, проблемы, их решения. В сб. Тритикале (вып. 4). Ростов-на-Дону, 2010. С. 74-78.

10. Кирильчук А. М. Оцінка генофонду тритикале озимого для створення сортів Поліського екотипу. Селекиія $і$ насінництво. 2014. Вип. 106. С. 24-33. DOI: 10.30835/24137510.2014 .42098 .

11. Грабовец А.И., Крохмаль А.В. Итоги и перспективы селекции озимой тритикале. В сб. Тритикале (вып. 6). Ростов-на-Дону, 2014. С. 29-36.

12. Парій Ф.М., Діордієва І.П. Оцінка низькостеблових форм чотиривидових тритикале за основними господарсько-цінними ознаками. Вісник Уманського національного університету садівниитва. 2014. № 1. С. 74-78. 
13. Москалець В.В., Москалець Т.З. Прояви модифікаційної здатності генотипів тритикале озимого лісостепового та поліського екотипів. Селекція $і$ насінництво. 2015. Вип. 107. С. 75-86. DOI: 10.30835/2413-7510.2015.54035.

14. Рябчун В.К., Мельник В.С., Капустіна Т.Б., Щеченко О.С. Урожайність тритикале ярого та іiі стабільність залежно від генотипу та умов середовища. Сортовивчення та охорона прав на сорти рослин. 2016. № 1(30). С. 37-44. DOI: 10.21498/2518-1017.1(30).2016.61765.

15. Харченко М.В., Волощук С.І. Параметри адаптивності, біологічні та господарські ознаки перспективних ліній озимого тритикале. Миронівський вісник. 2016. Вип. 3. С. 71-84.

16. Ковтуненко В.Я., Беспалова Л.А., Панченко В.В., Калмыш А.П. Направления и результаты селекции тритикале в ФГБНУ «Краснодарский НИИСХ им. П.П. Лукьяненко». Труды Кубанского государственного аграрного университета. Краснодар. 2017. № 66. С. $115-120$.

17. Уразалиев Р.А., Айнебекова Б.А., Таджибаев Д.Г. Селекция озимого гексаплоидного тритикале в Казахстане. Тритикале - культура XXI сторіччя: матеріали міжнар. наук.практ. конф. Інститут рослинництва ім. В. Я. Юр'єва НААН. 4-6 липня 2017. м. Харків. С. $52-53$.

18. Щипак Г.В., Матвієць В.Г., Рябчун Н.І., Щипак В.Г. Результати селекції гексаплоїдних тритикале на зимостійкість. Сортовивчення та охорона прав на сорти рослин. 2017. Т. 13, № 1. C. 43-54. DOI: 10.21498/2518-1017.13.1.2017.97257.

19. Москалець В.В., Москалець Т.3., Гриник І.В., Москалець В.І., Буняк Н.М. Агроекологічна та селекційна характеристика нового генетичного різноманіття тритикале озимого полісько-лісостепового екотипу. Селекиія і насінництво. 2019. Вип. 115. С. 124-136. DOI: 10.30835/2413-7510.2019.172795.

20. Stoyanov H. Response of Bulgarian triticale cultivars to unfavorable environments. Bulgarian Journal of Crop Science. 2020. No 57(6). P. 17-29.

21. Левченко О.С., Стариченко В.М. Особливості формування і прояву ознак зернової продуктивності у тритикале озимого. Зернові культури. 2020. Т. 4. Вип. 1. С. 20-27.

22. Hammer K., Filatenko A.A. \& Pistrick K. (2011). Taxonomic remarks on Triticum L. and $\times$ Triticosecale Wittm. Genet Resour Crop Evol. 2011. No 58. P. 3-10. DOI: 10.1007/s10722010-9590-4.

23. ×Triticosecale neoblaringhemii A. Camus in Page R D M. The Plant List with literature. Institute of Biodiversity, Animal Health and Comparative Medicine, College of Medical, Veterinary and Life Sciences, University of Glasgow. DOI: 10.15468/btkum2 accessed via GBIF.org on 2021-02-01.

24. Triticum neoblaringhemii (A.Camus) Mackey in Page R D M. The Plant List with literature. Institute of Biodiversity, Animal Health and Comparative Medicine, College of Medical, Veterinary and Life Sciences, University of Glasgow. DOI: 10.15468/btkum2 accessed via GBIF.org on 2021-02-01.

25. $\times$ Triticosecale rimpaui Wittm., 1933 in The International Plant Names Index Collaborators (2019). International Plant Names Index. DOI: 10.15468/uhllmw accessed via GBIF.org on 2021-01-30.

26. $\times$ Triticosecale semisecale (Mac Key) K.Hammer \& Filat., 2010 in The International Plant Names Index Collaborators (2019). International Plant Names Index. DOI: 10.15468/uhllmw accessed via GBIF.org on 2021-01-30.

27. Меженський В.М. До питання впорядкування українських назв рослин. Повідомлення 11. Тритикале (×Triticosecale Wittmack ex A.Camus). Сортовивчення та сортовипробування. 2019. Вип. 15, № 4. С. 325-336. DOI: 10.21498/2518-1017.15.4.2019.188416.

28. Triticosecale Wittmack ex A.Camus in GBIF Secretariat (2019). GBIF Backbone Taxonomy. DOI: 10.15468/39omei accessed via GBIF.org on 2021-01-30.

29. Пополнение, сохранение в живом виде и изучение мировой коллекции пшеницы, эгилопса и тритикале: методические указания. Санкт-Петербург: ВИР, 1999. 82 с.

30. Методика государственного сортоиспытания сельскохозяйственных культур. Москва, 1988. $121 \mathrm{c}$.

31. Доспехов Б.А. Методика полевого опыта. Москва: Агропромиздат, 1985. 351 с. 
32. Державний реєстр сортів рослин, придатних для поширення в Україні на 2021 рік. Міністерство розвитку економіки, торгівлі та сільського господарства України (Мінекономіки). Київ, 2021. С. 48.550 с.

33. Moskalets T.Z., Vasylkivskyi S.P., Morgun B.V., Moskalets V.I., Moscalets V.V., Rybalchenko V.K. New genotypes and technological indicators of winter triticale. Biotechnologia Acta. 2016. Vol. 9. № 1. P. 79-86.

34. Griffiths J., Murase K., Rieu I., Zentella R., Zhang Z.L., Powers S.J., Gong F., Phillips A.L., Hedden P., Sun T.P., Thomas S.G. Genetics characterization and functional analysis of the GID1 gibberellin receptors in Arabidopsis. Plant Cell. 2006. No 18. P. 3399-3414.

35. Peng J.R., Richards D.E., Hartley N.M., Murphy G.P., Devos K.M., Flintham J.E. 'Green Revolution' genes encode mutant gibberellin response modulators. Nature. 1999. No 400(6741). P. 256-261. DOI: 10.1038/22307.

36. Willige B.C., Ghosh S., Nill C., Zourelidou M., Dohmann E.M., Maier A., Schwechheimer C. The DELLA domain of GA INSENSITIVE mediates the interaction with the GA INSENSITIVE DWARF1A gibberellin receptor of Arabidopsis. Plant Cell. 2007. No 19(4). P. 1209-1220. DOI: 10.1105/tpc.107.051441.

37. Bernatzky R., Tanksley S.D. Genetics of actin-related sequences. Theoretical and Applied Genetics. 1986. No 72. P. 314-321.

38. Worland A.J., Korzun V., Roder M.S., Ganal M.W., Law C.N. Genetic analysis of the dwarfing gene Rht8 in wheat. Part II. The distribution and adaptive significance of allelic variants at the Rht8 locus of wheat as revealed by microsatellite screening. Theoretical and Applied Genetics. 1998. No 96. P. 1110-1120.

39. Korzun V., Melz G., Borner A. RFLP mapping of the dwarfing (Ddw1) and hairy peduncle (Hp) genes on chromosome 5 of rye (Secale cereale L.). Theoretical and Applied Genetics. 1996. No 92. P. 1073-1077.

40. Youssefian S., Kirby E.J.M., Gale M.D. Pleiotropic effects of the GA-insensitive Rht dwarfing genes in wheat: effects on leaf, stem, ear and floret growth. Field Crops Research. 1992. No 28. P. 191-210.

41. Кобылянский В.Д., Солодухина О.В. Развитие идей Н.И. Вавилова в современных исследованиях рода Secale L. Труды по прикладной ботанике, генетике и селекции. 2012. Вып. 169. С. 53-64.

\section{References}

1. Girko VS, Girko OV, Voloschuk SI. Influence of agroclimatic conditions on yield of winter triticale and efficiency of cultivation technology. Zb. nauk. pr. NNTs Institut zemlerobstva NAAN. 2010; 4: 213-223.

2. Moskalecz VV. Triticosecale Wittmack ex. A. Camus: ecosystem approach to research for the formation of sustainable crops. Donetsk: Noulidzh, 2014. 602 p.

3. Pykalo SV. In vitro selection of triticale for resistance to abiotic stressors (review). Myronivskyi visnyk. 2019; 9: 80-90.

4. Rybalka OI., Morhun VV., Morhun BV., Polishchuk SS. Genetic basis of a new direction of selection of original wheat quality classes of wheat (Triticum aestivum L.) and triticale (x Triticosecale Wittmack). Fiziolohiia roslyn i henetyka. 2019; 51(3): 207-240.

5. Moskalets VV, Moskalets TZ, Vasylkivskyi SP et al. Adaptability and stability mechanisms of Triticeae tribe to epiphytoparasites in anthropical ecosystem. Ukrainian Journal of Ecology. 2017; 7(2): 230-238.

6. Moskalets TZ., Kliuchevych MM., Moskalets VV. Resistance of winter triticale and soft wheat against Puccinia recondita Dietel \& Holw. Karantyn i zakhyst roslyn. 2015; 6: 1-3.

7. Shulyndin AF. Triticale - a new grain and feed crop. Kyiv: Urozhay, 1981. 49 p.

8. Dogan R, Kacar O, Coplu N, Azkan N. Characteristics of new breeding lines of triticale. J. Agric. Res. 2009; 4: 133-138.

9. Grib SI, Bushtevich VN. Selection of triticale in Belarus: results, problems, their solutions. Tritikale. 2010; 4: 74-78. 
10. Kyrylchuk AM. Estimation of winter triticale gene pool for creation of Polissya ecotype varieties. Sel. Nasinn. 2014; 106: 24-33. DOI: 10.30835/2413-7510.2014.42098.

11. Grabovets AI, Krohmal AV. Results and prospects of winter triticale breeding. In: Tritikale (issue. 6). Rostov-na-Donu, 2014. P. 29-36.

12. Parii FM, Diordiieva IP. Evaluation of low-stem forms of four-species triticale on the main economic and valuable features. Visnyk Umanskoho natsionalnoho universytetu sadivnytstva. 2014. № 1. S. 74-78.

13. Moskalets VV, Moskalets TZ. Manifestations of modification ability of triticale genotypes of winter Forest-Steppe and Polissya ecotypes. Sel. Nasinn. 2015; 107: 75-86. DOI: 10.30835/2413-7510.2015.54035.

14. Riabchun VK, Melnyk VS, Kapustina TB, Shchechenko OYe. Yield of triticale spring and its stability depending on genotype and environmental conditions. Plant Varieties Studting abd Protection 2016; 1: 37-44. DOI: 10.21498/2518-1017.1(30).2016.61765.

15. Kharchenko MV, Voloshchuk SI. Parameters of adaptability, biological and economic signs of perspective lines of winter triticale. Myronivskyi visnyk. 2016; 3: 71-84.

16. Kovtunenko VYa, Bespalova LA, Panchenko VV, Kalmyish AP. Directions and results of selection of triticale at the Krasnodar Research Institute of Agriculture named after P.P. Lukyanenko". Trudyi Kubanskogo gosudarstvennogo agrarnogo universiteta. 2017; 66: 115120.

17. Urazaliev RA, Aynebekova BA, Tadzhibaev DG. Breeding winter hexaploid triticale in Kazakhstan. Trytykale - kultura KhKhI storichchia: materialy mizhnar. nauk.-prakt. konf. Instytut roslynnytstva im. V.Ya. Yurieva NAAN. 4-6 July 2017. Kharkiv. P. 52-53.

18. Schipak GV, Matviets VG, Ryabchun NI, Schipak VG. Results of breeding hexaploid triticale for winter resistance. Plant Varieties Studting abd Protection. 2017; 13(1): 43-54. DOI: 10.21498/2518-1017.13.1.2017.97257.

19. Moskalets VV, Moskalets TZ, Hrynyk IV, Moskalets VI, Buniak NM. Agroecological and selection characteristics of a new genetic diversity of triticale winter Polissya-Forest-Steppe ecotype. Sel. Nasinn. 2019: 115: 124-136. DOI: 10.30835/2413-7510.2019.172795.

20. Stoyanov H. Response of Bulgarian triticale cultivars to unfavorable environments. Bulgarian Journal of Crop Science. 2020; 57(6): 17-29.

21. Levchenko OS, Starychenko VM. Features of formation and manifestation of signs of grain productivity in winter triticale. Zernovi kultury. 2020; 4(1): 20-27.

22. Hammer K, Filatenko AA, Pistrick K. Taxonomic remarks on Triticum L. and $\times$ Triticosecale Wittm. Genet Resour Crop Evol. 2011; 58: 3-10.

23. $\times$ Triticosecale neoblaringhemii A. Camus in Page R D M. The Plant List with literature. Institute of Biodiversity, Animal Health and Comparative Medicine, College of Medical, Veterinary and Life Sciences, University of Glasgow. DOI: 10.15468/btkum2 accessed via GBIF.org on 2021-02-01.

24. Triticum neoblaringhemii (A.Camus) Mackey in Page R D M. The Plant List with literature. Institute of Biodiversity, Animal Health and Comparative Medicine, College of Medical, Veterinary and Life Sciences, University of Glasgow. DOI: 10.15468/btkum2 accessed via GBIF.org on 2021-02-01.

25. $\times$ Triticosecale rimpaui Wittm., 1933 in The International Plant Names Index Collaborators. International Plant Names Index. 2019. DOI: 10.15468/uhllmw accessed via GBIF.org on 202101-30.

26. $\times$ Triticosecale semisecale (Mac Key) K.Hammer \& Filat., 2010 in The International Plant Names Index Collaborators. International Plant Names Index. 2019. DOI: 10.15468/uhllmw accessed via GBIF.org on 2021-01-30.

27. Mezhenskyi VM. On the issue of ordering Ukrainian plant names. Message 11. Triticosecale Wittmack ex A.Camus. Plant Varieties Studying and Protection. 2019; 15(4): 325-336. DOI: 10.21498/2518-1017.15.4.2019.188416.

28. Triticosecale Wittmack ex A.Camus in GBIF Secretariat. GBIF Backbone Taxonomy. 2019. DOI: $10.15468 / 39$ omei accessed via GBIF.org on 2021-01-30. 
29. Replenishment, preservation and study of the world collection of wheat, aegilops and triticale. Methodical instructions. Sankt-Peterburg: VIR, 1999. 82 p.

30. Methods of the state variety trials of agricultural crops. Moscow, 1988. $121 \mathrm{p}$.

31. Dospekhov BA. Methodology of field experiment. Moscow: Agropromizdat, 1985. 351 p.

32. State Register of plant varieties suitable for dissemination in Ukraine in 2021. Kyiv, 2021. P. 48.

33. Moskalets TZ, Vasylkivskyi SP, Morgun BV, Moskalets VI, Moscalets VV, Rybalchenko VK. New genotypes and technological indicators of winter triticale Biotechnologia Acta. 2016; 9(1): 79-86.

34. Griffiths J, Murase K, Rieu I, Zentella R, Zhang ZL., Powers SJ, Gong F, Phillips AL, Hedden $\mathrm{P}$, Sun TP, Thomas SG. Genetics characterization and functional analysis of the GID1 gibberellin receptors in Arabidopsis. Plant Cell. 2006; 18: 3399-3414.

35. Peng JR, Richards DE, Hartley NM, Murphy GP, Devos KM, Flintham JE. 'Green revolution' genes encode mutant gibberellin response modulators. Nature. 1999; 400(6741): 256-261. DOI: $10.1038 / 22307$.

36. Willige BC, Ghosh S, Nill C, Zourelidou M, Dohmann EM, Maier A, Schwechheimer C. The DELLA domain of GA INSENSITIVE mediates the interaction with the GA INSENSITIVE DWARF1A gibberellin receptor of Arabidopsis. Plant Cell. 2007; 19(4): 1209-1220. DOI: 10.1105/tpc.107.051441.

37. Bernatzky R, Tanksley SD. Genetics of actin-related sequences. Theoretical and Applied Genetics. 1986; 72: 314-321.

38. Worland AJ, Korzun V, Roder MS, Ganal MW, Law CN. Genetic analysis of the dwarfing gene Rht 8 in wheat. Part II. The distribution and adaptive significance of allelic variants at the Rht 8 locus of wheat as revealed by microsatellite screening. Theoretical and Applied Genetics. 1998; 96: $1110-1120$.

39. Korzun V, Melz G, Borner A. RFLP mapping of the dwarfing (Ddw1) and hairy peduncle (Hp) genes on chromosome 5 of rye (Secale cereale L.). Theoretical and Applied Genetics. 1996; 92: 1073-1077.

40. Youssefian S, Kirby EJM, Gale MD. Pleiotropic effects of the GA-insensitive Rht dwarfing genes in wheat: effects on leaf, stem, ear and floret growth. Field Crops Research. 1992; 28: 191-210.

41. Kobylyanskij VD, Solodukhina OV. Razvitie idej N.I. Vavilova v sovremennykh issledovaniyakh roda Secale L. Trudy po prikladnoj botanike, genetike i selekcii. 2012; 169: 53 64.

\title{
МИРОНОСЕЦЬ - НОВИЙ ПРОДУКТИВНИЙ І ВИСОКОБІЛКОВИЙ СОРТ ТРИТИКАЛЕ ОЗИМОГО, АДАПТОВАНИЙ ДО УМОВ ПОЛІСЬКО-ЛІСОСТЕПОВОГО І ЛІСОСТЕПОВОГО ЕКОТОПІВ УКРӒ̈НИ
}

\author{
Москалець В.В. ${ }^{1}$, Москалець В.I. ${ }^{2}$, Москалець T.3. ${ }^{1}$, Гриник I.В. ${ }^{1}$, Демидов О.А. ${ }^{3}$, Волощук С.I. ${ }^{3}$, \\ Хоменко С.O. ${ }^{3}$ \\ ${ }^{1}$ Інститут садівництва НААН України \\ ${ }^{2}$ Носівська селекційно-дослідна станція Миронівського інституту пшениці імені В.М. \\ Ремесла НААН України \\ ${ }^{3}$ Миронівський інститут пшениці імені В.М. Ремесла НААН України
}

Мета і задачі дослідження - створити новий продуктивний і високобілковий сорт тритикале озимого, адаптований до полісько-лісостепового і лісостепового екотопу України.

Матеріал та методика. Селекційну роботу зі створення нового різноманіття тритикале продовжували виконувати в навчально-науковому дослідному центрі Білоцерківського національного аграрного університету впродовж 2007-2017 pр. Контрольне та екологічне випробування проведено впродовж 2009-2019 рр. в умовах Полісся (Інститут сільського господарства Полісся НААН (2007-2009 рр.; попередники: зайнятий пар), Центрального 
Лісостепу (Миронівський інститут пшениці імені В.М. Ремесла НААН (2016-2019 рр.; попередники: гірчиця, соя, горох на насіння; Білоцерківський НАУ (2009-2016 рр.; попередники: зайнятий пар, картопля), Північного Лісостепу (Інститут садівництва НААН» (2016-2017 рр.; попередники: багаторічні трави). Засоби захисту рослин не застосовували. Вихідним матеріалом були сорти різного еколого-географічного походження вітчизняної і зарубіжної селекції - тритикале: Славетне (UA), Пшеничне (UA), Чаян (UA), ДАУ 5 (UA),Ураган (UA), Ладне (UA), Раритет (UA), Харроза (UA), Поліське 7 (UA), Адась (BLR), Woltario (POL), Утро (BLR), Pigmei (POL), Triticale 64 (HUG), Kandar (SVK), Gorun 1 (ROM), Haduk (ROM, Prader (SV), АД 1668 (RU), ПРАО 19 (RU), Корнет (RU) та ін. наданого на договірній основі НЦГРРУ IP ім. Юр'єва НААН. Гібридизацію виконували способом ручної кастрації материнських компонентів та запилення «твел-методом» через 2-3 доби після кастрації. Вивчення селекційного матеріалу проводили згідно методичних вказівок ВIP та методики Державного сортовипробування [30]. Математично-статистичну обробку даних проводили за Б.О. Доспєховим та з використанням комп'ютерних програм Statistica-5.5 та Excel-2003.

Обсуждение результатов. В умовах центрального Лісостепу в 2008 р. методом межсортової гібридизації в межах нотороду $\times$ Triticosecale і дворазовим індивідуальним добором 3 гібридної популяції, отриманої від схрещування (Августо х Ягуар) х K9844/93, в $\mathrm{F}_{2}-\mathrm{F}_{4} \mathrm{i}$ повторними поліпшуючими відборами в $\mathrm{F}_{10}$ виділено кращу лінію ЛЧ/97 (сорт Мироносець).

Показано, що новий сорт тритикале характеризується високою врожайністю - біля 7,5 т/га, при середній урожайності зерна в умовах перехідної зони Лісостеп-Полісся - 5,7 т/га, центрального Лісостепу - 6,3 т/га та Полісся - 3,5 т/га, високою стійкістю до вилягання, обсипання, ламкості колоса, проростання зерна в колосі, комплексною стійкістю до ураження збудниками бурої листкової іржі, борошнистої роси, фузаріозу колоса та пошкодження рослин гесенською мухою, високою морозо- та зимостійкістю, посухостійкістю (8,5-9 балів), зимостійкістю за штучного проморожування - близько 70 \% (критична температура вимерзання $-18,3^{\circ} \mathrm{C}$ ), стійкістю до весняних і осінніх заморозків - на рівні 9 балів.

Установлено, що рослини сорту Мироносець здатні регулювати свою продуктивність під впливом аномальних біотичних та абіотичних факторів середовища, залишаючи 3-4 (зрідка 1-3 шт.) продуктивних стебла, часто 1-3 стебла з недорозвинутим колосом і 1-2 підсіди (стебел без колоса).

Висновки. За даними кваліфікаційної експертизи зерно сорту Мироносець відноситься до середньобілкових (13,5\%). Сорт рекомендовано до вирощування в зонах Полісся i Лісостепу. Окрім цього, сорт Мироносець $є$ цінним для комбінаційної селекції як джерело короткостеблості.

Ключові слова: тритикале озиме гексаплоїдного рівня, новий сорт, агроекологічна та господарська хактеристика, донор короткостеблості.

\title{
МИРОНОСЕЦ - НОВЫЙ ПРОИЗВОДИТЕЛЬНЫЙ И ВЫСОКОБЕЛКОВЫЙ СОРТ ТРИТИКАЛЕ ОЗИМОГО, АДАПТИРОВАННЫЙ К УСЛОВИМ ПОЛЕССКО- ЛЕСОСТЕПНОГО И ЛЕСОСТЕПНОГО ЭКОТОПОВ УКРАИНЫ
}

\author{
Москалец В.В. ${ }^{1}$, Москалец Т. $3^{1}$., Грынык И.В. ${ }^{1}$ \\ ${ }^{1}$ Институт садоводства НААН Украины \\ Москалец В.И. ${ }^{2}$ \\ ${ }^{2}$ Носовская селекционно-опытная станция Мироновского института пшеницы имени В.Н. \\ Ремесла НААН Украины \\ Демидов О.А. ${ }^{3}$, Волощук С.I. ${ }^{3}$, Хоменко С.O. $^{3}$ \\ ${ }^{3}$ Институт садоводства НААН Украины
}


Цель и задачи исследования - создать новый производительный и высокобелковый сорт тритикале озимого, адаптированный к условиям полесско-лесостепного и лесостепного экотипов Украины.

Материалы и методика. Селекционную работу по созданию нового многообразия тритикале продолжали выполнять в учебно-научном исследовательском центре Белоцерковского национального аграрного университета в течение 2007-2017 гг. Контрольное и экологическое испытание проведено в течение 2009-2019 гг. в условиях Полесья (Институт сельского хозяйства Полесья НААН, 2007-2009 гг.; предшественники: занятый пар), Центральной Лесостепи (Мироновский институт пшеницы имени В.Н. Ремесла НААН, 2016-2019 гг.; предшественники: горчица, соя, горох на семена; Белоцерковский НАУ, 2009-2016 гг.; предшественники: занят пар, картофель), Северной Лесостепи (Институт садоводства НААН, 2016-2017 гг.; предшественники: многолетние травы). Минеральные удобрения и средства защиты растений не применяли. Гибридизацию выполняли способом ручной кастрации материнских компонентов и запыленности «твэл-методом» через 2-3 суток после кастрации. Изучение селекционного материала проводили согласно методических указаний ВИР и методики Государственного сортоиспытания. Математически-статистическую обработку данных осуществляли по Б.А. Доспехову и с использованием компьютерных программ Statistica-5.5 и Excel-2003.

Обсуждение результатов. В условиях центральной Лесостепи в 2008 методом межсортовой гибридизации в пределах ноторода $\times$ Triticosecale и двукратным индивидуальным отбором из гибридной популяции, полученной от скрещивания (фАвгусто х §̊Ягуар) х $\precsim$ К9844 / 93 позволили в $\mathrm{F}_{2}-\mathrm{F}_{4}$ и повторными улучшающими отборами в $\mathrm{F}_{10}$, выделить лучшую линию ЛЧ / 97 (сорт Мироносець).

Показано, что новый сорт тритикале характеризуется высокой урожайностью - более 7,5 т / га, при средней урожайности зерна в условиях переходной зоны Лесостепи-Полесье - 5,7 т /га, центральной Лесостепи - 6,3 т / га и Полесье - 3,5 т / га, высокой устойчивостью к полеганию, осыпанию, ломкости колоса, прорастанию зерна в колосе, комплексной устойчивостью к поражению возбудителями бурой листовой ржавчины, мучнистой росы, фузариоза колоса и повреждения растений гессенской мухой, высокой морозо-, зимо-, засухоустойчивостью (8,5-9 баллов). При искусственном промораживании тритикале при температуре минус $18,3{ }^{\circ} \mathrm{C}$ выживает около $70 \%$ растений. Сорт характеризуется также высокой устойчивостью к весенним и осенним заморозкам (9 баллов).

Установлено, что растения сорта Мироносець способны регулировать свою производительность при воздействии аномальных биотических и абиотических факторов окружающей среды, оставляя 3-4 (реже 1-3 шт.) плодоносящих стеблей, часто 1-3 стеблей с недоразвитым колосом и 1-2 подседы (стеблей без колоса), которые формируют прикорневую розетку.

Выводы. По данным государственного сортоиспытания зерно сорта Мироносець содержит 12,7-13,5\% белка и рекомендован для выращивания в агроэкосистемах Полесья и Лесостепи. Установлено, что сорт Мироносець является источником короткостебельности.

Ключевые слова: тритикале озимая гексаплоидного уровня, новый сорт, агроэкологическая и хозяйственная характеристика, донор короткостебельности.

\section{MYRONOSETS - A NEW PRODUCTIVE AND HIGH-PROTEIN WINTER TRITICALE CULTIVAR, ADAPTED TO THE WOODLANDS/FOREST-STEPPE AND FOREST-STEPPE OF UKRAINE}

Moskalets V.V.

Institute of Horticulture National Academy of Agrarian Sciences of Ukraine

Moskalets V.I. 
Nosivka Breeding and Research Station the V.M. Remeslo Myronivka Institute of wheat National Academy of Agrarian Sciences of Ukraine

Moskalets T.Z., GrynykI.V.

Institute of Horticulture National Academy of Agrarian Sciences of Ukraine

Demidov A.A., Voloshchuk S.I., Khomenko S.O.

The V.M. Remeslo Myronivka institute of wheat National Academy of Agrarian Sciences of Ukraine

The creation of new triticale genotypes, the potential of which to a certain extent would meet scientific and production needs, will never lose its relevance.

Purpose and objectives - to create a new productive and high-protein winter triticale cultivar, adapted to the Woodlands/Forest-Steppe and Forest-Steppe of Ukraine.

Materials and methods. The breeding work to expend the triticale diversity was continued at the Educational and Research Center of Bila Tserkva National Agrarian University in 2007-2017. The control and environmental trials were conducted in 2009-2019 in the Woodlands (Polissya Institute of Agriculture NAAS (2007-2009); predecessor: seeded fallow), central Forest-Steppe (V.M. Remeslo Myronivska Institute of Wheat NAAS (2016-2019); forecrops: mustard, soybean, pea for seeds; Bila Tserkva NAU (2009-2016); predecessors: seeded fallow, potato), and northern Forest-Steppe (Institute of Horticulture NAAS (2016-2017); forecrop: perennial grasses). No mineral fertilizers were applied. No plant protection measures were taken. Hybridization was performed by manual emasculation of female components. Plants were pollinated by the twirl method 2-3 days after emasculation. The breeding material was studied in compliance with the guidelines of the All-Union Research Institute of Plant Breeding and the methodology of the state cultivar trials. Data were statistically processed, as B.A. Dospekhov described, using Statistica-5.5 and Excel-2003 software.

Results and discussion. We focus on the importance of triticale for mankind both at the present and in the future. We retrospectively reviewed data on the creation of a new winter triticale cultivar, Myronosets. Bioecological features and morphological characteristics of the new cultivar are given. The grain yield and quality are also summarized. The article covers the quantitative parameters of dough and bread from Myronosets grain. We compared the yields, resistance to lodging, in-spike germination, resistance to fungal pathogens and unfavorable abiotic environmental factors in the new triticale cultivar and previously created ones.

The data of the 2019-2020 state variety trials of Myronosets are analyzed, and they indicate that the new cultivar has a high potential in agroecosystems of the Woodlands and Forest-Steppe of Ukraine.

Myronosets was found to be a source of the short stem $(\leq 90 \mathrm{~cm})$ in subsequent hybrid generations.

In 2008, interspecific hybridization within the notogenus $\times$ Triticosecale and double individual selection from $\mathrm{F}_{2}-\mathrm{F}_{4}$ hybrid populations derived from crossing ( $q$ Avhusto $\mathrm{x}$ तY Yahuar) $\mathrm{x}$ IK9844/93 followed by repeated improving selections in $\mathrm{F}_{10}$ allowed us to distinguish the best line, LCh97, which was later named as cultivar Myronosets.

The new triticale cultivar can give $>7.5 \mathrm{t} / \mathrm{ha}$. The average yield is $5.7 \mathrm{t} / \mathrm{ha}$ in the Forest-Steppe Woodlands transition belt, $6.3 \mathrm{t} / \mathrm{ha}$ in the central Forest-Steppe, and $3.5 \mathrm{t} / \mathrm{ha}$ in the Woodlands. It is noticeable for high lodging resistance, high shedding resistance, low spike brashness, resistance to in-spike germination, complex resistance to Puccinia recondita f. sp. tritici Rob. ex Desm (8.5 points), Blumeria graminis (DC.) Speer (9 points.), and Fusarium graminearum Schwabe (8.5 points) and to to the pest Mayetiola destructor Say (8.5 points), high frost tolerance, high winter hardiness, and high drought resistance (8.5-9 points). About $70 \%$ of plants survive the laboratory freezing at $-18.3^{\circ} \mathrm{C}$. The cultivar is also resistant to spring and autumn frosts (9 points).

Myronosets plants were revealed to be able to regulate their performance under the influence of unfavorable extreme bio- and abiotic factors, leaving 3-4 (more seldom 1-2) fruiting stems, often 1-3 stems with underdeveloped spikes and 1-2 unfertile stems without spikes, which form a radical rosette. 
Conclusions. As it was shown in the state variety trials, Myronosets is a mid-protein cultivar and recommended for cultivation in agroecosystems of the Woodlands and Forest-Steppe. Myronosets was proven to be a source of the short stem

Key words: hexaploid winter triticale, new cultivar, agroecological and economic characteristics, donor of the short stem. 